\title{
THE PATTERN OF DUE DILIGENCE OF THE ENTREPRENEUR PROVIDING THE PROPERTY PROTECTION SERVICE WHICH IS THE SUBJECT OF COMPULSORY PROTECTION
}

\author{
IWONA SZYMCZAK \\ University of Szczecin, Faculty of Management and Economics of Services, POLAND \\ e-mail: iwona.szymczak@usz.edu.pl
}

RECEIVED

ACCEPTED

JEL

CLASSIFICATION

KEYWORDS

ABSTRACT
18 January 2018

2 September 2018

K12

protection of properties, contract for the provision of services, the pattern of due diligence

Economic activity consisting in the provision of services in the field of protection of persons and property is an important branch of the economy due to the protection of public safety. It is subject to licensing, but the legislator goes even further, because the Act on the Protection of Persons and Property not only defines the principles of conducting this activity, but also indicates categories of areas, facilities and equipment, which ought to be subject to mandatory protection (Article 5 of Act of the Protection of Persons and Property, called later: APPP). The subject of this article the due diligence standard applicable to entrepreneurs performing protection services for facilities which are subjects to mandatory protection. The main goal is pointing out how it differs from the due diligence standard of entrepreneurs protecting other objects (not subject to mandatory protection). This issue will affect the scope of the entrepreneur's liability for improper performance of the contract for the protection service. Interpretation of existing legal regulations indicates that in the case of objects which are subjects to compulsory protection the entrepreneur's liability due to improper performance of the contract is more strict. There is an high level of the pattern of due diligence in relation to the general standard of due diligence to perform the protection service in relation to other facilities that are not subject to compulsory protection and they have no protection plans (art. $355 \S 2$ of the Civil Code called later: CC).

\section{Introduction}

The legislator requires that certain objects used for strategic reasons of functioning of the State, regardless of their ownership status, are subjects to mandatory protection (Gozdór, 2005, p. 14). These are objects that are not only public property, but also belong to private or public-private entities (e.g. banks, factories producing, renovating and storing firearms, military devices and equipment, as well as buildings and facilities located in the open areas 
which destruction or damage may cause a threat to human life or health, the environment material damage, such as power plants, sewage treatment plants).These objects are burdened with a high degree of risk connected with numerous threats for these properties. Although theirs protection can be performed both by internal security services (being part of the organizational structure of a protected entity), as well as by entrepreneurs who provide this service based on art. $750 \mathrm{CC}$, however, the legislator introduced an additional form of administrative supervision which is called "agreement on a protection plan" that is not required to other facilities (Wojtal, Milewicz, 2008, p. 27).

\section{Contract for the provision of property protection services}

The legislator does not regulate the content of the contract for the provision of this service. Therefore, according to the doctrinal view, the contract for the provision of services in the field of property protection is an unnamed contract to which art. 750 CC is applied appropriately (Ogiegło, 2005, p. 372). In science, there are discrepancies regarding the legal qualification of this contract, either as a contract of diligent action or as a result agreement. For better understanding a nature of problem and resolving this dispute I start with analysis on issue, which is what is the subject of this contract. According to art. 3 APPP, protection of property means activities preventing crimes and offenses against property, as well as counteracting the occurrence of damage resulting from these events and preventing entry of unauthorized persons to the protected area. However, according to the doctrinal definition, the contract of diligent action includes the obligation of the debtor consisting in careful conduct in pursuit of a specific aim, which, however, the debtor has no obligation to achieve (Pajor, 1983, p. 162). The mere fact of not achieving the goal is not enough to accept their liability for damages. Additional legal requirement, which is needed for responsibility of entrepreneur, is his guilt. A similar view was presented in the judgment of the Court of Appeal in Katowice of 30 October 2012 (III AUa 226/12, LEX No. 1236507): ,the basic criterion distinguishing the contract for the provision of services from the contract for specific work is the fact that the contractor is not obliged to achieve specific result."

Turning to the analysis of the scope of the entrepreneurs' duties in the security service, they are obliged to take actions described not only in contract but in the protection plan of object. They are obliged to maintain the existing state of security (protection purpose). If this goal (result) is not achieved, the issue of the entrepreneur's liability for occurred damages appears. However, the mere fact of not achieving the goal is not enough to accept their liability for damages. As legal requirement for taking responsibility of entrepreneur is his negligence which is the lightest level of guilt (contrary for contract for the work, in which, although a contractor acts with due diligence, but he fails to achieve the intended effect, he is liable for improper performance of the contract).

As to the burden of proof, from art. $471 \mathrm{CC}$ comes out a presumption of guilt, which charges the debtor (who is the entrepreneur). Therefore, he must give evidences for all circumstances to prove a lack of his guilt. For example, he should prove that security staff have carried out all activities resulting from security procedures which are listed in the contract or protection plan of object, what in practice may be difficult to prove. The fact that there was no negligence in their actions, is required to be proved for the negative circumstance, that is why P. Pajor (1983, p. 164) rightly points out that it is easier to indicate the specific cause that caused the incident and which would not burden the debtor (in our case, the entrepreneur performing the service). The proof of lack of fault remains when a specific cause cannot be found.

As the conclusion, there is no doubt that for providing protection service the due diligence contract is much more appropriate than a contract for specific work. Nevertheless, under the freedom of contracts, the parties may 
agree on contract of a specific result. If the wording of contract is unclear, the legal interpretation of such a contract depends on whether the entrepreneur is obliged to achieve a specific goal or he is only obliged to take action to pursuit this goal. Of course, the qualification of this contract does not depend on the lingual meaning of the separated terms used, but on the whole legal context, in which they are applied in the contract, in particular regarding the scope of liability of entrepreneur. An example is a contractual wording: "The Contractor takes full responsibility for damages arising as a result of non-performance or improper performance of duties by security personnel, as well as for losses resulting from burglary or theft or destruction of property by unknown perpetrators while performing protection by their employees".

\section{Models of due diligence in property protection services}

The contractor of the property protection service should proof that he carries out his service action with a due diligence to be released from the contract liability. Thus, the question arises of determining the content of the pattern of this professional diligence (art. $355 \S 2 \mathrm{CC}$ ). In the literature the prevailing view is that it is an objective measure of diligence (Sośniak, 1980, p. 127; Nipperdey, 1957, p. 1781). This view is also found in common law systems (Cook, Oughton, 1993, p. 173). In this point, it will be discussed models of due diligence in property protection services. There are two models of due diligence. First one is applied to an entrepreneur, who conducts a business in property protection service for real properties which are subject of mandatory protection, but the second one is for real properties which are not subject of mandatory protection.

I start from the second model, which is less strict than first one. The entrepreneur protecting the object from outside the catalog referred to in art. 5 APPP should, in principle, follow contractual provisions, unless the rules of law state otherwise (it is Act on the Protection of Persons and Property). He is bound by the contract and by all documents, which are component part of it. The internal documents defining the procedures for the protection of the object, which have been "accepted” within the organizational structure of the entity ordering the service, should be attachments to the contract. Otherwise, these internal procedures are binding only the employees within internal structural unit, which is the subject of protection service, but are not binding for protection staff, who are subordinated to the entrepreneur. They become the source of rights and obligations for the contractor (service contractor), if they are included as an integral part of the contract (they will be listed therein as attachments).

So in this case the entrepreneur's liability for non-performance or improper performance of the contract is based on art. $471 \mathrm{CC}$, according to which the debtor is obliged to compensate the damage resulting from nonperformance or improper performance of the obligation, unless the non-performance or improper performance results from circumstances for which the debtor is not liable.

Now I come to first model of due diligence for entrepreneur in the field of services related to property under the mandatory protection, it is shaped more strict. There is duty to prepare draft of protection plan for object, so entrepreneur is burdened with the higher level of precaution. He is obliged to predict potential risks connected with protected object. Thus, it is necessary to submit a draft of protection plan to the Police. Legal regulations defining the rights and obligations of the entrepreneur and security staff are mandatory. Therefore, the parties of contract for the protection service cannot modify the scope of statutory competences (rights and obligations), in particular the manners of use of direct coercion measures and firearms, referred to in the Act on coercive measures and firearms, in a manner that would lead to the violation of the mentioned regulations. 


\section{Significance of protection plan of object for standard of due diligence in property protection services}

The entrepreneur shall act with due diligence if he follows the protection procedures based on the contract (and the documents constituting its components). However, the protection rules for an areas and objects, which are the subject to obligatory protection should be treated differently, because there is a document called a protection plan (the same remarks will also apply to the regulations referred to in art. 6 APPP). According to art. 7 (1a) APPP, the head of the unit, who directly manages the areas, facilities and devices listed in the records referred to in art. 5 (5) APPP, or a person authorized by him, shall agree on a protection plan to these areas, facilities and equipment with the Chief of Provincial Police, but in the area of terrorist threats, with the Director of the Internal Security Agency. It is an obligatory document, required by law (art. 7 APPP), so the entrepreneur providing service for this kind of areas and objects is obliged to comply with the arrangements resulting from this plan. This document binds the entrepreneur regardless of whether it has been delivered to him and is as an integral part of the contract or not.

What is more, it should be assumed that the entrepreneur's level of due diligence should be higher, because the objects mentioned above are strategically important subjects of protection (Enerlich, Wojtal, Milewicz, 2000, p. 14). Therefore a higher degree of predictability of potential threats is expected. It is reflected in the lingual meaning of term "agree". It is not a strict control measure used by the Police (Chief of Provincial Police). As a rule, administrative bodies use imperative means such as permission or consent. The agreement on protection plan, which is referred to in art. 7 (3) APPP, is a specific hybrid, which is a combination of administrative law construction and civil law construction (it includes both reconciliation elements or negotiation elements). Both parties, who is entrepreneur and the Chief of Police should cooperate to achieve common goal. From one side, the idea of how to organize a protection method should come from the applicant (the head manager of a unit whose property is subject to mandatory protection), but from other side, through this semantic flexibility of the term „agreement” the legislator gives an interpretive guideline that the content of a protection plan shall be agreed by both parties (the Police is due to correct any defects in this document).

It seems that purposely the legislator did not use the term "approval”, but the term „agreement”, which suggests that the Police cannot be passive and he is required to give constructive proposals for a protection plan. It is also worth to mention the comments of other authors who rightly points out that the legislator does not authorize the Minister of the Interior and Administration to issue executive provisions in this matter. The police take into account their own requirements, which are included in: Methodology for agreeing plans for protection of areas, facilities and equipment subject to mandatory protection by Police Headquarters Guidance (Kręgulec, Pajorski, 2015, p. 7). The term "agree" contains not only the element of conducting negotiations, but it should be treated as a suggestion for the administrative body (Police) to strive for a consensus, to which both sides should follow, because until a certain concept of protection service is formally accepted, the object to mandatory protection is not properly protected. It can therefore be argued that the decision to refuse approval is a final measure (if the civilian law element fails, i.e. negotiations). Nevertheless if such a refusal is issued, one of the objections that the party may raise in the appeal proceedings is lack of cooperation of the body in the procedure agreeing on a protection plan.

Thus, returning to the pattern of due diligence in the performance of the protection service in the area of compulsory protection facilities, the contracting entrepreneur is obliged not only to comply with the existing protection plan, regardless of whether it was included in the provisions of the contract to which he is a party, but also the he is responsible for taking into account the current threat. As the consequence of it he should making proposal 
of the changes in this plan adapting the protection measures to existing risks and dangers (undertaking initiatives of a change of plan). Such a thesis is supported by the wording of art. 7 on connection with art. 26 (2) point 1 APPP, in which is said that the entity obliged to agree on the plan is the head of the protected facility, however the plan is prepared by a person entered on the list of qualified physical protection employees (or a person entered on the list of qualified technical security employees when the plan includes performing activities referred to in art. 3 point 2 APPP). T. Alexandrowicz (2001, p. 7) explains that the legislator divided activities in two parts. First kind of activities is done by the manager of organizational unit. He submits an application to agree protection plan. Second kind of activity is making draft of the protection plan which is required to be made by an employee with an entry on the list of qualified employees, because the first one usually do not have the required entry on the list of protection employees (Alexandrowicz, 2001, p. 7). In practice, it means that if the entrepreneur is the entity that performs this service, he will be liable with the preparation of the draft plan. Likewise, W. Kotowski (2003, p. 12) rightly pointed out that if the bank uses third party services, operational risk management should charge the service provider and thus the bank's management bodies are exempt from this responsibility, as they do not have direct control over the performance of services (Kotowski, 2003, p. 14).

Thus, as regards the level of due diligence required of an entrepreneur protecting an object, which is a subject to mandatory protection, it is higher than for other entrepreneurs in this field. The former should be expected to be more diligent in anticipating and preventing potential threats. His scope of duties that he should perform is listed in the plan of protection, which is agreed with the Voivodship Commander of the Police. If the provisions of the contract are inconsistent with the protection plan, priority is given to the protection plan.

\section{Conclusions}

Under Polish law, a private entrepreneur can provide protection services to both public and private property. However, an entrepreneur providing such a protection service relating to an object, which is a subject to mandatory protection is expected to follow statutory requirements, which are more strict than for other entrepreneurs in this area. The administrative agenda (the Police) controls the manner of performing this service, in particular, cooperate with entrepreneur in administrative procedure of agreeing on the protection plan. The entrepreneur is primarily bound by the protection plan, and only in the remaining scope by the provision of the contract of this service. However, in the case of contradiction as to the content of the contract and the protection plan, he should comply the requirements arising from the latter document. Therefore, his liability for improper performance of the obligation regarding protection services primarily covers the improper performance of the provisions of the protection plan that binds him by law, from the moment of signing the contract, regardless of whether such a document has been delivered to him as an attachment to this contract or not. In the remaining scope he shall follow the provisions of contract.

\section{Method}

The topic of this paper is related to national law. The main method is an analysis of Polish regulation, which may help to interpret national law. It dominates at earlier research stages. There is also a synthesis which leads to for setting proposals for a future legislative amendments (so called: conclusion de lege ferenda). 


\section{References}

Act on coercive measures and firearms of 24 May 2013 (consolidated text OJ from 2017 item 1120, with changes OJ from 2018, item 138, OJ from 2018, item 106).

Aleksandrowicz, T.R. (2001). Komentarz do ustawy o ochronie osób i mienia. Warszawa: LexisNexis.

Civil Code (Polish Civil Code (consolidated text OJ from 2018, item 1025, 1104, called later: CC.

Cook, J., Oughton, D. (1993). Common Law of Obligations. London Dublin: Butterworths.

Enerlich, M., Wojtal, J., Milewicz, M. (2000). Ochrona osób i mienia, licencja II stopnia. Toruń: Dom Organizatora.

Gozdór, L. (2005). Komentarz do ustawa o ochronie osób i mienia. Legalis, wyd. 1, Komentarz do art. 7. Warszawa: C.H. Beck.

Kotowski, W. (2003). Ochrona osób i mienia. Komentarz LEX/el. 2003 - komentarz do art. 7, stan prawny: 1 sierpnia 2003 r., Warszawa: Wolters Kluwer.

Kręgulec, R., Pajorski P. (2015). Ustawa o ochronie osób i mienia. El/Lex Komentarz do art. 7. Warszawa: Wolters Kluwer.

Ogiegło, L. (2005). System Prawa Prywatnego. In: J. Rajski (ed.), Prawo zobowiązań - część szczegółowa, t. 7. Warszawa: C.H. Beck.

Pajor, T. (1983). Charakter zobowiązania a odpowiedzialność dłużnika. In: Studia z Prawa Prywatnego, Księga pamiątkowa dla uczczenia Prof. A. Szpunara. Warszawa-Łódź: Uniwersytet Łódzki.

Sośniak, M. (1980). Należyta staranność. Katowice: Uniwersytet Śląski.

The Act on the Protection of Persons and Property of August 22, 1997, hereinafter called: APPP. Journal of Laws of 2017, item 2213, with changes in Journal of Laws of 2018, item 650, Journal of Laws of 2018, item 138.

Wojtal, J., Milewicz, M. (2008). Ochrona osób i mienia- licencje, bezpieczeństwo imprez masowych. Toruń: Dom Organizatora.

Cite this article aS: Szymczak, I. (2018). The pattern of due diligence of the entrepreneur providing the property protection service which is the subject of compulsory protection. European Journal of Service Management, 3 (27/2), 461-466. DOI: 10.18276/ejsm.2018. $27 / 2-56$. 